In this issue:

Beverly Lynch Resigns as ACRL Executive Secretary

John Crowley Named Editor of C\&RL News

Guidelines for Bibliographic Instruction in Academic Libraries .

ACRL Candidates, 1977 Elections

News From the Chapters

Tentative Schedule of ACRL Midwinter Meetings

News From the Field

People

Classified Advertising

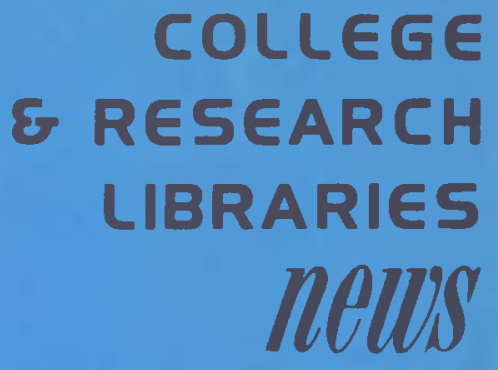

NO. 11 DECEMBER 1976

\title{
Beverly Lynch Resigns as ACRL Executive Secretary
}

At the end of December, Beverly Lynch will resign as executive secretary of ACRL to become university librarian at the University of Illinois, Chicago Circle campus on January 1, 1977. Dr. Lynch has served as ACRL's chief staff officer since October 1972 and has been a dynamic and moving force in the association. She is a dedicated professional who is seriously concerned with organizational problems and their solutions; and because she has been extremely sensitive to ACRL's inner tensions and to its relationship with ALA, she has been able to minimize conflict and to focus ACRL's energies on vital issues.

During her tenure, ACRL has received three J. Morris Jones awards, a three-year grant from the Mellon Foundation for the Academic Library Internship Program for Administrators of Black College Libraries, and a grant from the Council on Library Resources for a survey of academic library salaries. Major projects completed include the revision of standards for college libraries, revision of standards for university libraries, and the publication of a new edition of Books for College Libraries. Dr. Lynch has been especially successful in establishing relationships with other professional organizations and in raising the level of consciousness of nonlibrarian groups to the problems of academic librarians.

As university librarian, Dr. Lynch will direct a staff of 150 and will hold the ranks of professor and dean.

Dr, Lynch holds degrees from North Dakota State University, the University of Illinois, and

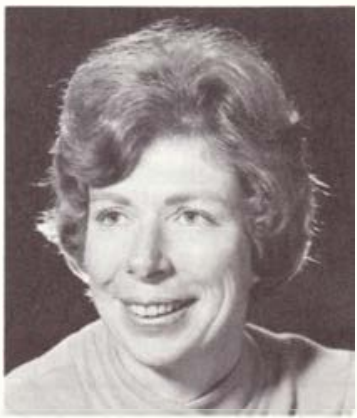

Beverly Lynch

the University of Wisconsin. Her major academic interests are the theory of organization and management. In addition to serving as ACRL's executive secretary, Dr. Lynch has worked in reference (Plymouth, England), serials (Yale and Illinois), and cataloging (Marquette University). She has taught in the library schools of the universities of Chicago and Wisconsin, has served as consultant to a number of institutions and organizations, and has been in frequent demand as a program speaker. Dr. Lynch has also been published widely in library and other professional journals.

Members of ACRL thank Dr. Lynch for her four years of creative service as their executive secretary and will wish her continued success in her new post.

Connie R. Dunlap President of ACRL 